\title{
The History of Explosives in Switzerland - Selected Highlights
}

\author{
Beat Berger*
}

\begin{abstract}
Around the time that Switzerland was established, the use of black powder or gun powder was also mentioned for the first time in this area. For the following five hundred years black powder was the only explosive known in Switzerland. The performance of black powder depended very much on the production process. In the 19th century, Prof. Schönbein synthesized the new energetic material cellulose nitrate at the University of Basel. Also in the 19th century the use of fireworks in Switzerland was mentioned for the first time. During World War I a new cellulose nitrate propellant plant was built in Wimmis. Today, new energetic materials which are not available commercially are synthesized and characterized in the laboratories of armasuisse.
\end{abstract}

Keywords: Explosives · High explosives · History · Propellants · Pyrotechnics

When we look back at the historical evolution of explosives in Switzerland, first of all we have to look back on the political situation in central Europe about 1000 years ago. At this time the central part of Europe of today was split up into several Duchies. For example there was the Duchy of Habsburg, the Duchy of Burgundy and the Duchy of Lombardy. In 1191 Duke Berchtold of Zähringen founded a new city on a half island of the river Aare. The city rapidly became an important place for the trade from North to South and therefore was in a position to gain very fast knowledge of the lastest news and newest inventions. At this time an English monk called Roger Bacon made experiments with compositions containing sulphur, charcoal, and saltpetre. It seems that he gained the knowledge of such compositions from Dutch sailers who brought it back from China.

In the 13th century, the century during which Switzerland was founded, a German monk with the original name Konstantin Ancklitzen, today better known as Berthold Schwarz, also made experiments with such

${ }^{*}$ Correspondence: B. Berger armasuisse

Science and Technology

Feuerwerkerstrasse 39

$\mathrm{CH}-3602$ Thun

Tel.: +41332284465

Fax: +41332284601

E-Mail: beat.berger@armasuisse.ch compositions to find a new golden ink. During his experiments he remarked the energetic effect of the reaction products during the burning of such compositions. He made his experiments in a pot, in German called 'Büchse'. That is the reason why in all German dialects the common word 'Büchse' is still today used for a rifle.

In 1291 some cantons allied to a new state, called Switzerland. About 80 years later, in 1371 black powder (Schwarzpulver) or gun powder was mentioned for the first time in the area of today's Switzerland. The city of Basel hired a gunmaker from the Alsace. His job was not only to manufacture rifles; he also had to produce the necessary black powder. His work contract was the first works contract in the area of the new country Switzerland.

In 1383 the City Republic of Bern, now part of the Swiss Alliance, wanted to conquer the small neighbouring town called Burgdorf [1]. A siege was started together with soldiers of the other members of the Alliance. The castle and the city of Burgdorf are located on a hill. To destroy the castle and the city wall the besiegers used big slingshots. In German this weapon is called 'Blide' but today hardly anyone knows the meaning of this expression. However the besiegers did not succeed in assaulting the castle or the city. Now the commanders of the Bernese troops remembered that the city bought some pieces of a brand new weapon not too long before. There were mortars and the first types of rifles. These weapons were brought immediately to the troops in front of the castle of Burgdorf, but at this time no black powder was available. Therefore allied soldiers from the canton of Luzern were sent over the Gotthard down to the Lombardy to buy some black powder. At this time no member of the Swiss Alliance was able to produce black powder. After bargaining the black powder for the Bernese mortars was brought over the Gotthard pass down to the area of Luzern and then over the Brünig pass down to Unterseen, a village which is today part of Interlaken. From there it was shipped down the Lake of Thun and the river Aare to the city of Berne and then brought to Burgdorf. When the black powder finally arrived in Burgdorf, the siege was over, because the City Republic of Bern had bought the city of Burgdorf in the meantime. We know all this on behalf of the state settlement of the City Republic of Bern for the year 1383/84.

In the 15 th century the production of black powder was started in some cantons of the Swiss Alliance due to the hazardous transport and the dependence on foreign countries. The city cantons such as Bern, Zürich and Luzern started to hire foreign rifle makers who had to produce the necessary black powder, too. The required sulphur for the black powder was bought in the south of Italy, the saltpetre was extracted from the earth under the stables of farms and the charcoal was produced from hazel and alder bushes.

Later in this century farmers or their family members ran the black powder plants. The mixing process was done by hand and the resulting black powder was more or less a fine powder. Mostly the interest of the farmers in the production was 


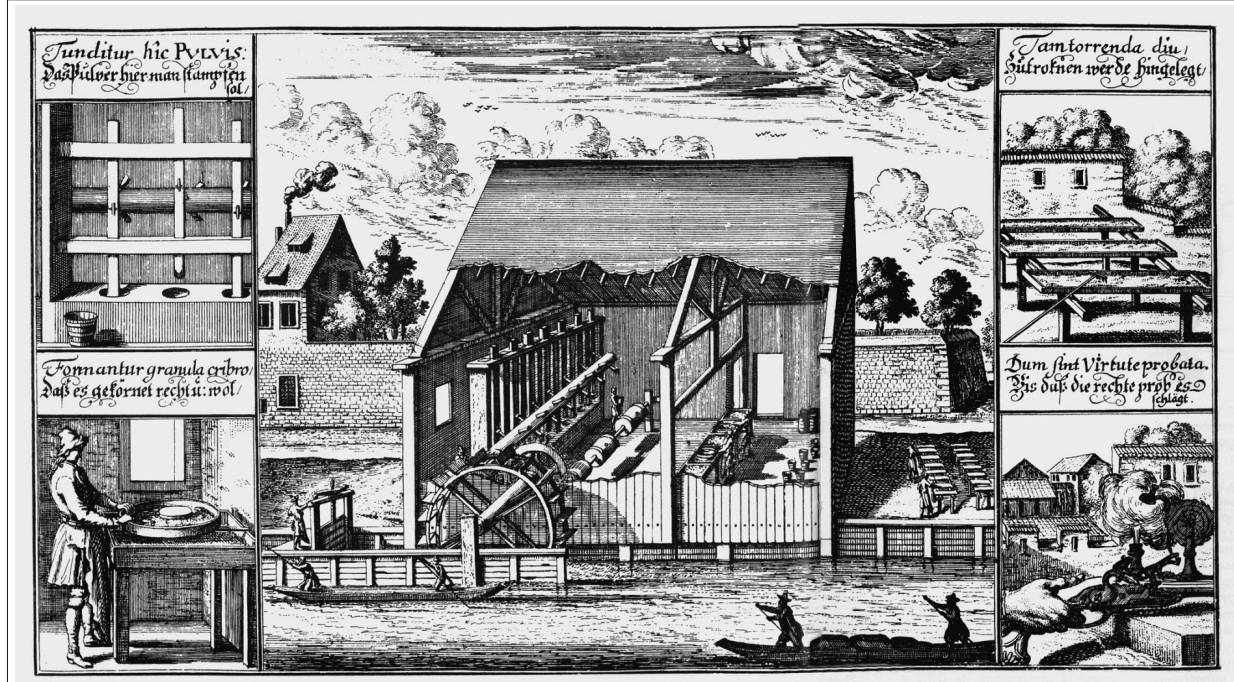

Fig. 1. The different steps during black powder production: water-driven black powder mill

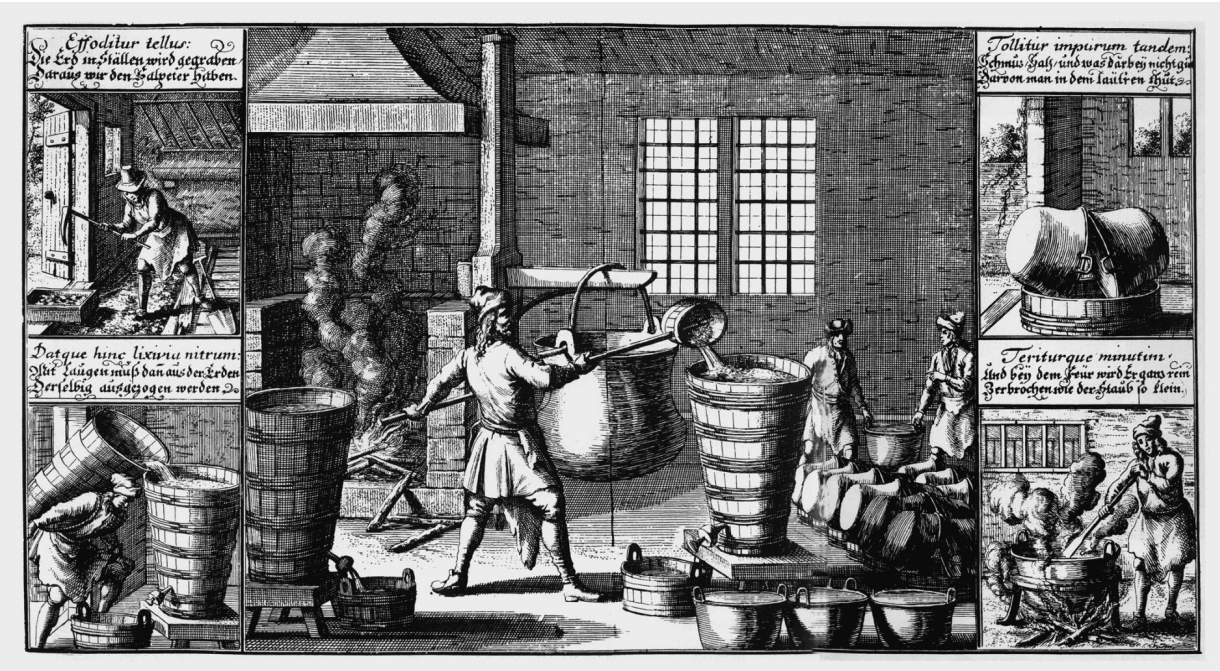

Fig. 2. Different steps during the recovery of potassium nitrate (saltpetre)

not too high, because it was an additional job they had to do. Therefore the quality of the black powder varied widely [2].

In the year 1476 the Swiss Alliance had to fight against the army of the Duke of Burgundy. They went into the battle with a few mortars and rifles only. The Swiss solders won the famous battle of Murten. The booty was 420 mortars, 800 rifles and 300 tons (probably $50 \mathrm{~kg}$ barrels) containing black powder [3].

In the 16th century the handmade black powder production changed to a mechanical process. Old water-driven corn mills were used for the production. Fig. 1 shows a water-driven black powder mill [4]. A lot of such black powder mills were located in the area of the City Republic of Bern, some in the city of Zürich, Luzern and other cantons.

The government of the City Republic of Bern sold licenses to people who were then allowed to recover saltpetre $\left(\mathrm{KNO}_{3}\right)$ or to cut the special switches from the hazel and alder bushes. The recovery process of the very important saltpetre is depicted in Fig. 2.

For the licensed saltpetre producers the farmers had, due to a governmental order, to prepare a dry place, water and dry wood.

This license selling was on one hand a good business for the City Republic of Bern; on the other hand the government was able to control the black powder production and the trade.

In 1652 some of the family plants were closed and the four biggest black powder mills in the Bernese canton were put under government control. One of them was located in an area called Worblaufen, close to the city of Bern.

At this time Bernese black powder became very famous as the result of its excellent performance. To find out why the Bernese black powder was better than that produced by the city of Zürich the councillor Landolt, who was responsible for the production and storage of black powder of the city of Zürich, went to Strasburg and bought there a test mortar. The bullet of this mortar had a weight of 60 pounds. For the firing 3 ounces of black powder were used, i.e. about $100 \mathrm{~g}$. The firing angel was $45^{\circ}$. Immediately a shooting was arranged to compare the quality of the different black powders [5]. The measured flight distances in Klafters (Klafter is an old unit to measure the length. 1 Klafter is the length of the extended arms of a man, the values could therefore lie in the range of 1.7 to $2.9 \mathrm{~m}$ ) of the bullet were the following:

- French black powder: 110 Klafter

black powder from Zürich: 104 1/2

Klafter

Bernese black powder: 112 Klafter

In the year 1696 black powder was used for the first time in Switzerland as a civilian explosive for the construction work on the Albula pass [6].

During all this time black powder production remained a dangerous job. A lot of severe accidents are mentioned, e.g. the explosion of the black powder mill in the city of Zürich in 1723.

Till the 19th century black powder was the only known and used explosive in Switzerland. In Europe as well as in Switzerland the 19th century was the century of the big inventions [6]. During the time period of 1799-1868 Christian Friedrich Schönbein worked as a professor at the University of Basel. His working field was the investigation of the influence of nitric acid on different organic materials. Once he also treated cellulose with nitric acid, dried the material and ignited it. The new material burnt very fast: nitro cellulose had been invented. Prof. Schönbein informed the Swiss War Council about the new substance. The council organized a mortar firing to compare the new material with black powder. The performance of nitrocellulose was about 2.5 times greater than those of black powder, but due to its instability the new explosive material could not immediately replace black powder.

In 1848 Switzerland changed its political system from an alliance of different states to a federal state, with one parliament, with a capital, with a federal army and last but not least with its own responsibility for black powder production, the socalled Powder Laws [7]. Later this responsibility was extended to the production and the trade of all explosives.

In 1853 the Swiss Government founded a new black powder mill in the Frenchspeaking part of Switzerland close to the village of Aubonne. At this time there were three black powder facilities in Switzerland, distributed over the whole country [7]:

- the black powder mill at Worblaufen,

- the black powder mill at Chur,

- and the black powder mill at Aubonne.

Today only the mill of Aubonne still produces black powder. 
The year 1855 was very important for the history of pyrotechnics in our country. In this year a young Bernese teacher was asked by the owner of a hotel on the Lake of Brienz to illuminate the big waterfalls close to the hotel. Prof. Hamberger succeeded in colouring illumination of them by using pyrotechnic compositions. For many years this illumination was an exciting tourist attraction for visitors from the whole of Europe. Therefore Prof. Hamberger founded his own firework company on the shore of the Lake of Brienz. Today the company still produces fireworks for big events [8].

In 1873 and 1895 the first production plants for high explosives were founded in Switzerland. These were Alfred Nobel's plant in Isleten, on the shore of the lake of Luzern and the plant in Gamsen, which is located in the canton of Wallis. Which reasons led to the choice of the two places? It is very simple; both places were close to the planned big construction sites Gotthard and Simplon/Lötschberg railway tunnels. On the basis of an exclusive contract with the Swiss Government Nobel could deliver all high explosive used for the construction work on the Gotthard railway tunnel and the big fortresses which were built in this area. It was a good business for him.

In 1890 nitro cellulose production for the Swiss Army was started in the black powder mill at Worblaufen. This led to a black powder production stop at this place in the same year. In 1914, at the beginning of World War I the Swiss artillery troops needed large amounts of the new nitro cellulose gun propellant. But the capacity of the existing production plant in Worblaufen was too small. An enlargement of the exist- ing facility was not possible because the city of Bern had grown around it. Therefore in 1917 the Swiss Government decided to build a new gun powder plant near the village of Wimmis, which is located near Interlaken. The Powder Plant Wimmis, today better known under the name Nitrochemie Wimmis, still produces gun propellant. The construction work was finished in 1919, after the war had ended. At this time nobody was interested in buying gun propellant anymore and the new factory did not receive any orders. In this situation the management of the plant had an idea. It decided to produce pasta with the new machines. However this pasta was too expensive; it was impossible to sell it. Finally this pasta became part of the salary of the workers of the plant.

The rest of the history of explosives in Switzerland can be told in a few words. In 1947 the high explosive Hexogen (RDX), which had already been used in Europe during World War II was synthesized by the explosive plant Dottikon for the first time in Switzerland. Today this plant produces drugs against heart attack and a lot of other chemicals. In 1971 the Laboratories of the Swiss Defense Procurement Agency synthesized the high explosive Octogen (HMX) for the first time in our country. At this time we thought that the time of new inventions in the field of high explosives would be over. Nevertheless in 1997 CL-20, a new high explosive of the US Navy Labs in China Lake was synthesized and characterized for the first time in Switzerland by the Laboratories of the Defense Procurement Agency.

This short overview about the history of energetic materials in Switzerland is for the first 500 years the history of only one explosive composition, black powder, an explosive composition that can be used as a propellant, as a high explosive, and as a pyrotechnic composition. During the last 150 years a lot of new energetic molecules, energetic compositions as well as inorganic redox systems were developed producing much more energy than black powder. However it is interesting to see that black powder is still used in modern weapon systems.

Received: March 30, 2004

[1] C.A. Jenny, 'Stiftung der alten, Schweizerischen Freyheit', Jenny Buchhandel, Bern, 1827.

[2] K.L. Schmalz, 'Bern Pulver', Sonderdruck Bernerzeitschrift für Geschichte und Heimatkunde, 3, Verlag Paul Haupt, Bern, 1956.

[3] H. Schönenberger, 'Das Schiesspulver gestern und heute', Hauszeitung Pulverfabrik Wimmis, Wimmis, 1978/ 1979.

[4] A. Bruniholz, C. Hildebrandt, H. Leutwyler, 'Pulver, Bomben und Granaten', Lang Druck AG; Liebefeld, 1983.

[5] J. Meyer, '400 Jahre Zürcher Pulver', Neujahrsblatt der Feuerwerkergesellschaft, Zürich, 1975.

[6] F. Trimborn, H. Lück, 'Zur Geschichte der Sprengstoffe und der Sprengarbeit', Nobel Hefte, 1981.

[7] B. Campiotti, Eidgenössiache Pulververwaltung, KMV, Bern, 1973.

[8] H. Ineichen, 'Kleine Feuerwerkdokumentation', Oberried, 1980. 